\title{
Analysis of the Legislative Function of Banyuasin Regency Legislative Council Members during the Recess Period
}

\author{
Muhammad Quranul Kariem ${ }^{1}$, Noor Ishmatuddin ${ }^{2}$ \\ ${ }^{1}$ Government Science Study Program, Universitas Indo Global Mandiri, Indonesia \\ ${ }^{2}$ Government Science Study Program Universitas Indo Global Mandiri, Indonesia \\ Corresponding Author: mquranul@uigm.ac.id ${ }^{1}$
}

\section{Article Info}

Keyword:

Recess carried;

Legislation;

Participation;

\begin{abstract}
This study aims to determine the effectiveness of the recess carried out by the Banyuasin District Parliament with a theoretical approach from Harel Arnon on direct legislation. The qualitative approach method used interviews with informants, then the data found were broken down and analyzed with theory, and conclusions drawn. The results found that the recess period carried out by the Banyuasin District Parliament in the process was effective because it could encourage increased community participation in development issues. The factor that made the exercise of the recess period effective was because the majority geographical area was quite difficult to reach by board members.
\end{abstract}

Kata Kunci:

Masa Reses ;

Legislasi;

Partisipasi;

\begin{abstract}
Abstrak: Penelitian ini bertujuan untuk mengetahui efektifitas masa reses yang dilakukan oleh DPRD Kabupaten Banyuasin dengan pendekatan teoritis dari Harel Arnon tentang legislasi langsung. Metode pendekatan kualitatif digunakan menggunakan wawancara dengan narasumber, selanjutnya data yang ditemukan diurakan dan dianalisa dengan teori, serta diambil kesimpulannya. Hasil penelitian menemukan bahwa masa reses yang dilakukan oleh DPRD Kabupaten Banyuasin dalam prosesnya berjalan efektif karena dapat mendorong meningkatnya partisipasi masyarakat dalam isu-isu pembangunan. Faktor yang menjadikan pelaskanaan masa reses efektif adalah karena wilayah geografis yang mayoritas cukup sulit dijangkau oleh para anggota dewan.
\end{abstract}

Article History: Received; 2020-01-22 Revised; 2020-02-20 Accepted; 2020-02-22

\section{INTRODUCTION}

Democracy is an alternative chosen by the Indonesian people in running the government. The 2019 election contest that has ended has produced people's representatives at the DPR, DPD, Provincial DPRD, and Regency/City DPRD levels. The members of the people's representatives who occupy each of these institutions must carry out their primary duties and functions as members of the legislature. They are carrying out the legislative function (making legislation), the oversight function (overseeing government performance), and the budget function (i.e., approving or rejecting budget plans).

This article will describe one function, the legislative function of the people's representative institutions at the regional level, in the Banyuasin District Parliament for the 2019-2024 period. Banyuasin Regency is one of the largest districts in South Sumatra, with a total of 45 legislative members from 6 electoral districts. In the electoral district (electoral area 3) Banyuasin Regency, which consists of Banyuasin II, Karang Agung Ilir, Sumber Marga Telang, and Muara Telang, was won by six candidates (detiksumsel.com, 2019). 
This constituency of some areas in the form of waters can only be reached by speedboat in its geographical location. This condition is a challenge for elected legislators to be able to absorb the aspirations of the people. DPRD members have a recess period to capture public aspirations. This period is a form of implementing the legislative function. According to Law number 17 of 2014 concerning the MPR, DPR, DPD, and DPRD or commonly referred to as MD3 Law, the recess period is a period of activities outside the trial, which is carried out by individuals or groups to visit their constituencies, to absorb the aspirations of the community. There have been several studies conducted regarding the recess period, for example, the Apriliansyah study (2019) of the sample taken, stated $78.64 \%$ of respondents that the recess period undertaken by board members was excellent and effective. Chaniago (2017) also supports this conclusion. He mentions that the results of the recess period are to be conveyed in the plenary session of the board members, distributed at the development planning deliberations, and included in consideration of the preparation of the policy budget.

Goni, Nayoan \& Liando (2019) also obtained a similar conclusion. They stated that the absorption of aspirations conducted by members of the Minahasa District DPRD was quite effective. The board members could place themselves as communicators who conveyed ideas to the public, through the process of rejection, consideration, and finally accepted to set priorities in development. The research from Setiyowati \& Ispriyarso (2019) found that the selection of people's aspirations can be made before the discussion of the RAPBD and in the implementation of the APBD. The method done is by Musyawarah Rencana Pembangunan or MusRenBang (Development Planning Conference), maximizing online media, print media, Focus Group Discussion, or going down to the community directly, using the recess period or optimizing the role of local non-governmental institutions such as Non-Governmental Organizations, community organizations and political parties.

However, different conclusions come from Hidayatullah \& Pribadi (2017). They state that the results of recess under legislative members were difficult to follow up, and the community had never felt the realization because of too many legislative and local government interests. The results of research from Maulina, Agustino, \& Dewi (2018) found that the recess period carried out by board members in Banten Province was ineffective and was only a formality, with the distribution of money and goods. Research from Afnan \& Abidin (2017) also showed similar results, where there were still many aspirational funds distributed that were not on target, due to many fictitious groups acting on behalf of the people.

Negative perceptions about the legislative institution are from the process of recess in the community and the issue of the implementation of its function. Kariem (2018) found that the DPRD DIY only conducted its oversight function of the executive on administrative formality. While in some of these studies, two different perceptions explain the effectiveness carried out by board members in the recess period, there are positive results as well as negative results. The legislative function performed by board members has a lot of problems and dynamics in their implementation. These dynamics arise due to socio-cultural conditions in each environment.

The aspirations of the people are absolute in democracy. In the constitution, sovereignty is in the hands of the people. It means that people have the highest position in the life of the nation and state. As explained earlier, although many areas in Banyuasin Regency South Sumatra are in the form of territorial waters, this has become a new dynamic in seeing and absorbing people's aspirations. Board members who are in such geographical areas must have different methods and approaches from board members who are in urban areas or large cities. Therefore, this article will describe the strategy used by members of the Banyuasin Regency DPRD in the 
electoral districts in some areas in the form of waters. It will also discuss the results of the recess period, and dynamics that occur in the process of implementing the legislative function.

\section{RESEARCH METHOD}

This study used a qualitative descriptive method with a case study approach (Creswell, 2018) because it will explain empirical facts about the implementation of the recess in Banyuasin Regency, South Sumatra. The researchers used primary data in the form of interviews with members of the Regency DPRD (electoral district 3) and secondary data in the form of results from the recess period conducted. The data analysis technique used the Milles \& Huberman approach in Hardiansyah (2012), where the first step was to collect data, the second was to display data, and the third was to draw conclusions explaining the analysis using a theoretical approach.

\section{RESULT AND DISCUSSION}

The first recess period for members of the Banyuasin Regency DPRD for the period 20192020 was in December 2019. The recess period for the Electoral District of 3 Banyuasin districts was carried out in a group manner, in which almost all those elected to structural positions in the DPRD. The recess period was first revealed by the Deputy Chairman II of the Banyuasin District Parliament as follows.

"The first recess period is that people are waiting after they feel they chose in the 2019 election yesterday, what can be fought for by members of the council, I have a constituency of about 85 thousand."

In the description of the interview results above, these expectations reflect the fulfillment of minimum requirements in democracy, one of the six conditions expressed by Burkens, et al. in (Ilmar, 2016). They state that everyone has political rights in the form of the right to freedom of opinion and assembly. Communities gather during the recess of the board members and express their opinions about the expectations of the board members. The community also stated their needs during the recess of the council members. The priority was the issue of road and bridge infrastructure.

Road and bridge infrastructure is the most needed by the community according to informants, considering that electoral area 3 in Banyuasin Regency consists of swamps (water). The respondents revealed that in the electoral district, there were 43 villages, but only eight villages had road access for vehicles (car). These conditions make the community encourage members of the council to make infrastructure the priority in development. Water areas with a reasonably large population are quite complex challenges, given the budget needed to capture the aspirations of the community through recess is not small.

The budget of the board members is quite limited in carrying out the recess period. The guest speaker revealed that the budget given by the Banyuasin Regency DPRD secretariat was around 30 million, where the limited budget the council members had to visit villages that the majority were not easily reached in their constituent areas and held the aspiration net event. This condition reflects the dynamics of gathering aspirations during the recess, which are not the same as other regions.

The second priority aspiration, as expressed by the resource person, is regarding the issue of Education. He revealed: 
"... The second priority requested by the community in my electoral area is Education, school construction, and school renovation. It becomes important for the community."

Public awareness of education reflects the right socio-cultural conditions where the community has high expectations in the sector. Education has indeed become the primary means of creating superior and quality human resources so that it can become a chaperone in advancing the region. It is a significant turning point for Banyuasin District, given the high level of awareness and trust of the community in education. In addition to education, resource persons revealed that what the community wanted was the fulfillment of rights in health issues. Projection of public health programs and policies in the Banyuasin Regency, according to sources, will be encouraged to be more comfortable and more efficient. The community only needs to show a National Identity Card (KTP) if they do not have BPJS.

The third aspiration priority is that the community asked for the resolution of land disputes in several areas in the Banyuasin Regency. The respondent outlined:

"... there is a case in the Puskesmas in my electoral district, so the Puskesmas land belongs to community $A$, he does not want the land to be sold but used for health centers, but suddenly the office health has a claim for the land .., we will close it later ... "

The community members also experience this condition, so the issue of land certification is a priority in the aspirations conveyed by the community. Claims on land are indeed vulnerable to occur; the number of land that does not have a certificate triggers a more significant problem in the future. DPRD is an essential part of encouraging local governments to resolve land dispute issues, bearing in mind that it is also a national priority program for now.

The three priority aspirations of the people in electoral area 3 of the Banyuasin Regency are exciting to be studied in more depth using a theoretical approach to legislation directly from Arnon (2008: 21-32). He reveals seven direct legislative approaches. They are direct legislation that can improve internal rules, strengthening democracy, and representative institutions, overcoming weaknesses in the legislation, increasing democratic participation in general, encouraging legislators to focus again, increasing citizen participation and education, and resolving political controversies. The results of the recess can answer several indicators in Arnon's theoretical concepts.

The first is that the recess period carried out by members of the council with the geographical location that is not easy will encourage the committee to formulate internal rules that can support the effectiveness of the implementation of the recess in different regions. To legislators during the recess has strengthened democracy and representative institutions, where an aspiration is a form of trust of the people's trust with those who represent it in the official forum that is the recess period, which is part of the agenda of the people's representative institutions. Matters conveyed during the recess are also fundamental issues, where the aspiration will later encourage the DPRD to carry out the functions of legislation, supervision, and budget in resolving the problems mentioned. The second is that aspirations during the recess can fix weaknesses in the legislative process because, in products produced by legislative institutions in the form of laws and regulations, they often have a 'gap' between those representing and those represented.

The 'gap' legislation product, which is a weakness, can be resolved with the same consensus and understanding to solve the problem. Furthermore, the process of expressing aspirations during this recess also showed an increase in participation in democracy. The 
development priorities of the community demonstrate such participation, conveyed to the board members. This concern is evidence of the increased community participation in issues in the region. The geographical condition of the village is challenging to reach by vehicles and consists of water areas. This issue can encourage the members of the council to be more focused on collecting aspirations collectively, where this recess period, the councilors in electoral districts 3 carry out the recess period with a joint strategy.

The ongoing recess will create a dynamic political system. A progressive political system requires a lot of input, namely in the form of aspirations from citizens. The condition of an ongoing and dynamic political system indicates that the education of citizens is growing. Finally, the presence of councilors during recess in every village can reduce and even resolve political controversies between the government and those governed by stakeholders and the community. Misunderstandings between policymakers and the public, two-way communication patterns, and community-based interests usually cause political controversies.

Seven approaches in Arnon's theoretical perspective used in this Analysis can provide a more systematic picture of direct legislation carried out by board members. From the various literature studies described at the beginning of this article, the indicators in the Arnon approach are complete and systematic. The indicator is an appropriate measure in describing the activities of board members during the recess in electoral area 3 in Banyuasin District, South Sumatra.

Arnon's theoretical approach regarding direct legislation, of the seven indicators, has been fulfilled. It means that the recess period carried out by members of the Banyuasin District Parliament in the 2019-2024 period in its implementation process can be quite useful because it can accommodate public affairs in increasing participation and democratization. Political rights in the form of opinions in the formal forums in government characterize that democracy has been operating as it should. If this condition continues, the process of democratization will sustain and encourage the community to become more developed in democratic life.

\section{CONCLUSION}

The first recess period in the Electoral District 3 of the Banyuasin Regency was carried out collectively by the members of the Banyuasin Regency DPRD for the period 2019-2024. Based on a theoretical approach from Harel Arnon on direct legislation, that the implementation of the recess period was quite useful to encourage and increase public participation in legislative institutions as an official state institution that plays a central role in the administration of regional government. The effectiveness is shown by the enthusiasm of the community in political participation, namely conveying their basic needs to the people's representatives through the 'recess' forum. The excitement of the community that arises in the delivery of these aspirations is due to geographical factors in the form of waters in the area, so that psychologically and sociologically the aspiration net activities held by board members become social instruments that are needed by the community.

\section{ACKNOWLEDGMENT}

Thank you to the Indo Global Mandiri University for providing support in this research, then to the Banyuasin Regency DPRD who have collaborated in this research, and the master in government science, Yogyakarta Muhammadiyah University for encouraging this article to be published.

\section{REFERENCES}

Arnon, Harel. 2008. A Theory of Direct Legislation, New York: LFB Scholarly Publishing 
Creswell, John W. 2018. Penelitian Kualitatif \& Desain Riset, Yogyakarta : Pustaka Pelajar

Hediansyah, Haris. 2012. Metodologi Penelitian Kualitatif untuk Ilmu Ilmu Sosial, Jakarta : Salemba Humanika.

Ilmar, Aminuddin. 2016. Hukum Tata Pemerintahan, Jakarta : Prenadamedia Group

Afnan, M. A. M., \& Abidin, Z. (2017). Dana Aspirasi dan Pola Hubungan Konstituen Dengan Wakil Di Dewan Perwakilan Rakyat Aceh. Jurnal Ilmiah Mahasiswa Fakultas Ilmu Sosial \& Ilmu Politik, 2(2), 428-443.

Apriliansyah, M. (2019). Efektifitas Pelaksanaan Masa Reses Anggota DPR RI Periode 20142019 di Daerah Pemilihan Jabar IV. Jurnal Serasi, 17(1), 15-24.

CHANIAGO, G. (2017). Hasil Reses DPRD dalam Pembuatan Kebijakan di Kota Gunungsitoli. Politeia: Jurnal Ilmu Politik, 8(2).

Goni, M. G., Nayoan, H., \& Liando, D. (2019). Penyerapan Aspirasi Masyarakat Oleh Anggota DPRD Di Kabupaten Minahasa Selatan Periode 2014-2019. Jurnal Eksekutif, 3(3).

Hidayatullah, H., \& Pribadi, U. (2017). Analisis Jaring Aspirasi Melaui Reses Dewan Perwakilan Rakyat Daerah Lombok Timur Tahun 2015. Journal of Governance and Public Policy, 3(2), 339-367.

Kariem, M. Q. Analisis Fungsi Pengawasan Dprd Provinsi Daerah Istimewa Yogjakarta (Diy) Terhadap Implementasi Keistimewaan. Politika: Jurnal Ilmu Politik, 9(2), 61-81.

Maulina, S. A., Hamid, A., \& Dewi, S. K. (2018). Penjaringan Aspirasi Masyarakat melalui Reses Anggota DPRD Provinsi Banten (Studi Kasus pada Masa Persidangan ke II Tahun Sidang 2017/2018).

Setiyowati, L., \& Ispriyarso, B. (2019). Upaya Preventif Dalam Rangka Pengawasan Terhadap Apbd Melalui Penjaringan Aspirasi Masyarakat Oleh Dprd. Jurnal Pembangunan Hukum Indonesia, 1(2), 250-265.

Undang - Undang Nomor 17 Tahun 2014 tentang MPR, DPR, DPD, dan DPRD

Hasil wawancara dengan Wakil Ketua DPRD Kabupaten Banyuasin periode 2019-2024 pada 12 Januari 2020 di Kota Palembang

45 Anggota DPRD Banyuasin dilantik, 17 Wajah Baru, diakses pada : https://www.detiksumsel.com/45-anggota-dprd-banyuasin-dilantik-17-wajah-baru/ 11 September 2019 